\title{
Taxpayer's Religiosity, Religion, and the Perceptions of Tax Equity: Case of South Korea
}

\author{
Byung Wook Jun ${ }^{1}$ and Sung Man Yoon ${ }^{2, *}$ (i) \\ 1 Graduate School of Science in Taxation, University of Seoul, Seoul 02504, Korea; bwjun@uos.ac.kr \\ 2 Department of Business Administration, Seoul National University of Science and Technology, \\ Seoul 01811, Korea \\ * Correspondence: ysm6123@seoultech.ac.kr; Tel.: +82-02-970-6440
}

Received: 18 September 2018; Accepted: 25 October 2018; Published: 30 October 2018

\begin{abstract}
The purpose of this study is to investigate the effect of religiosity and religion on tax equity. Most prior studies have argued that higher taxpayers' religiosity reduces tax evasion and increases the level of tax morale. Various studies have also shown that tax evasion and morale vary with perceptions of tax equity, including exchange, horizontal, and vertical equities. However, the relationship between religiosity and tax equity has not been studied actively. Especially in Korea, there has been considerable debate about the implementation of taxation for clergies. Therefore, the relationship between religiosity and tax equity will be analyzed clearly using Korean survey panel data. The results of this study show that religiosity and religion do not affect exchange and horizontal equity; however, each religion affects vertical equity. This implies that economic and social incentives are more effective than religiosity and religion on taxpayers' tax evasion or morale.
\end{abstract}

Keywords: religiosity; religion; tax equity; exchange equity; horizontal equity; vertical equity

\section{Introduction}

Taxes are generally the most important source of financing public goods and services, and taxation is a powerful policy tool for income redistribution. Fostering voluntary cooperation is a major concern among policymakers for the tax system to succeed, especially when it depends greatly on self-assessment. However, if taxpayers perceive the current tax system as inequitable, they would have unfavorable attitudes toward taxes and might lose confidence in the system. Thus, taxpayers may respond to inequity by engaging in questionable activities to reduce their tax dues. Tax evasion refers to intentionally paying less tax than the law requires as a deliberate act of noncompliance by illegal means (Hessing et al. 1988).

For policymakers to establish an optimal tax system, it is crucial to understand the underlying motivations that may affect compliance behavior. Economists often view an individual's tax behavior as a rational choice to maximize his or her own material outcomes. However, behavioral scientists presume that individuals are motivated not only by economic incentives, but also by social and psychological factors. Behavioral approaches, in other words, emphasize how taxpayers' attitudes and beliefs toward the tax system are formulated. For example, in a comprehensive review of tax compliance research, Jackson and Milliron (1986) note that equity perceptions are associated with behavioral intentions regarding tax compliance. Similarly, Spicer and Becker (1980) suggest that taxpayers may choose tax evasion to adjust for perceived inequities.

Although social and psychological factors as well as tax justice may affect taxpayers' tax evasion, other previous studies have shown that religion or belief affects tax evasion. Additionally, in Islamic and Christian teaching, sadaqah (contribution) or tithing is highly encouraged to nurture the values of giving to the needy, which are then simply applied in contributing to the development of the nation by 
paying taxes (Benk et al. 2016). Also, in Korea, religion is connected with politics and becomes a social issue (Hong et al. 2016) (e.g., the debate over legislation of clergy taxation).

Notwithstanding the importance of equity perceptions in tax compliance or tax evasion behavior, scarce research has been conducted on the factors that may affect taxpayers' different perceptions on tax equity. Therefore, this study attempts to discover the relationship between religiosity, religion, and taxpayers' perception of equity of the Korean tax system. In particular, using attitudinal data from a finance panel survey conducted by the Korea Institute of Public Finance from 2009 to 2016, we focus on taxpayers' judgments of exchange, horizontal, and vertical equities. Exchange equity refers to perceived benefits from the government in exchange for taxes paid. Horizontal and vertical equities refer to the equitable distribution of tax burdens among taxpayers of similar income levels and the differential distribution of tax burdens between those of different income levels, respectively. Therefore, the purpose of this study is to investigate the effect of religiosity and religion on the perception of tax equity. There are three main categories of tax equity: Exchange equity is the equity between the taxpayer and the government, while horizontal and vertical equities refer to the equity between and among taxpayers, respectively.

The study contributes to academic research on religion and tax equity by highlighting the religion or religiosity of taxpayers' distributive equity perceptions. Although tax behavioral studies have determined the impact of socio or demographic variables on taxpayer compliance, they do not provide clear explanations as to why these differences exist. We posit that, based on social and psychological approaches that emphasize the role of taxpayers' attitudes toward the tax system, demographic variables affect taxpayers' perceived equity, as equity perceptions represent their judgments and beliefs about the tax system. This study investigates religion and socio-economic factors that impact taxpayers' perceptions of distributive tax equity, including exchange, horizontal, and vertical equity, to address the missing link between demographic variables and tax compliance. Therefore, analyzing whether religion or religiosity has a greater influence on recognizing tax equity than economic incentives will contribute to the view that religion and politics are independent, not confrontational.

The remainder of the paper is organized as follows: Section 2 provides a review of prior literature on the perceptions of tax equity. Section 3 presents potential demographic determinants of equity perceptions and an empirical research design. The last section discusses the empirical results and their implications, with policy recommendations.

\section{Literature Review}

\subsection{Literature on the Determinants of Tax Equity}

The first economic analysis of taxpayer compliance behavior can be traced to the pioneering work of Allingham and Sandmo (1972), whose analytical model (henceforth, "the AS model") is a straightforward application of the "economics of crime" (Becker 1968) to individual income tax reporting decisions. It is assumed that taxpayers are motivated only to maximize their individual financial outcomes by trading the benefits of evasion for its costs. A taxpayer's decision to evade taxes is analogous to portfolio choices between a certain tax position, or honest reporting, and the risky prospect of evasion (Sandmo 2005). Thereafter, Yitzhaki (1974) modified the AS model by incorporating a realistic penalty structure, in which fines are proportional to the taxes evaded. The AS model partially modified by Yitzhaki (1974) is the ostensibly standard economic model of tax evasion, and produces comparative statistics to prove that state tax evasion is negatively associated with such economic deterrence factors as tax rates, detection probability, and penalty rate.

The standard model's predictions have been extensively examined, both empirically and experimentally (Kirchler et al. 2008). However, the standard economic approach fails to satisfactorily account for the high level of compliance observed in the real world. Considering a low detection probability and mild fines, a taxpayer's rational choice in the economic deterrence framework involves evading most of his or her taxable income. Alm et al. (1992) stressed that the tax compliance behavioral 
puzzle may be the reason why people pay taxes, not evade them. The same researchers also provided experimental evidence that some people willingly comply with their tax obligations, even when no enforcement exists. Second, the negative relationship between tax rates and tax evasion is somewhat counterintuitive and is sometimes called the "Yitzhaki puzzle." Empirical findings on the effects of higher tax rates on compliance are inconsistent. Because economic incentives alone do not adequately describe tax evasion behavior, recent studies have increasingly focused on noneconomic factors that should be considered in the analysis of compliance decisions.

A significant paradigm shift has occurred from exclusively focusing on economic factors associated with individual decision making towards social and psychological factors (Alm et al. 1992). Many researchers underline the role of noneconomic factors influencing taxpayer compliance behavior, such as tax ethics (Alm and Torgler 2011), social norms (Wenzel 2004), equity perceptions (Wenzel 2003), and trust (Feld and Frey 2002), in solving the compliance puzzle. Individuals are not motivated by purely financial outcomes. Fiscal psychologists contend that noneconomic factors strongly influence taxpayers' compliance behavior. Frey (1997) asserts that individuals are endowed with civic virtue, which can be crowed out if the government violates procedural equity norms. According to Frey and Feld (2002), the relationship between taxpayers and the government can be modeled as an implicit, psychological contract. Similarly, the psychological tax contract suggests that tax inequity can crush taxpayers" "tax morale" or intrinsic motivation to pay taxes by breaching the contract.

Justice in social and psychological tax behavioral approaches is classified as distributive, procedural, and retributive justice (Wenzel 2003). They refer to equitable treatment by the government, by tax authorities, and of tax evaders, respectively. Tax scholars underline the importance of equity and justice considerations in taxpayer compliance decisions. For example, Wenzel (2002) claimed that taxpayers are more concerned about procedural and distributive justice than personal outcomes when they strongly identify with the nation. Frey and Feld (2002) believed that taxpayers' willingness to pay taxes will increase when tax officials treat them respectfully. If taxpayers perceive that rule breakers are not properly punished, they may no longer feel obliged to adhere to the laws (Rechberger et al. 2010). Among these three dimensions of justice, we concentrate on the demographic factors that shape distributive equity perceptions.

Distributive tax justice refers to the equitable exchange of benefits and costs, and the equitable distribution of tax burdens among taxpayers. Three distributional dimensions of exchange, horizontal, and vertical equities exist. Exchange equity refers to taxpayers' perceived benefits in exchange for taxes paid. Horizontal equity requires a similar treatment among those who are equal, whereas vertical equity requires an appropriate differentiation among those who are unequal (Porcano 1985). Similarly, Jackson and Milliron (1986) concluded in their review of tax compliance studies that tax equity seems to involve at least two dimensions: The equity of the trade- or the benefits received for the tax dollars given - and the equity of the taxpayer's burden relative to that of other individuals (i.e., taxpayers' perceptions of the tax system's horizontal and vertical equities).

Equity theory suggests that individuals who feel they are in an inequitable situation strive to eliminate their distress by restoring equity (Adams 1965). In a tax compliance context, taxpayers who perceive the tax system as inequitable are likely to report less income to restore that equity (Cowell 1992). One research strand stresses the strong link between the perception of distributive equity and tax evasion. For example, Bordignon (1993) contended that tax equity perceptions may be more important than the tax rate itself in influencing compliance behavior. Further, Roberts and Hite (1994) reported that taxpayers' perception of the tax system's equity plays an important role in noncompliance behavior. Kim et al. (2005) provide experimental evidence that both conventional economic forces and equity considerations are significant in reporting decisions. They assert that the compliance puzzle can be reconciled by incorporating behavioral factors, such as perceptions of exchange inequity, into the analysis. Drawing on the social psychology of distributive tax justice, the study begins with the assumption that perceived distributive tax equity can be measured using the three aspects of equity perceptions. 
Recently, Kirchler et al. (2008) integrated economic and psychological factors into two comprehensive dimensions: the trust in, and power of, authorities. They established a conceptual "slippery slope" framework for tax compliance, which postulates that power and trust define different interaction climates between tax authorities and taxpayers. Tax compliance can be achieved either by exerting power or by strengthening trust. Tax morale, such as social norms and perceived equity, may significantly enhance voluntary compliance, whereas audits and fines come into play in cases of enforced compliance.

\subsection{Literature on the Relationship between Religiosity (or Religion) and Tax Morale}

Religiosity has been commonly considered in previous research using two orientations-religious affiliation and religious commitment (Benk et al. 2016). Religious affiliation is the self-identified association of a person to a religion, such as being Muslim, Christian, or Buddhist. Religious commitment is defined as the degree to which a person adheres to his/her religious values, beliefs, and practices and uses them in daily living (Worthington et al. 2003). Religious commitment can be divided into two types, namely intrapersonal religiosity that originates from the beliefs and attitudes of an individual, and interpersonal religiosity that develops from the involvement of an individual with a religious community or organization (Benk et al. 2016). Church attendance, church participation, religious education, religious beliefs, importance of religion, religious guidance, and trust in the church to represent religious observance are some of the proxies used to measure religiosity commitment in prior literature (Torgler 2006).

However, these measurements are not linked clearly in prior studies, neither with intrapersonal nor with interpersonal religiosity, except for two studies by Benk et al. (2016) and Mohdali and Pope (2014), which investigated the impact of religiosity commitments (intrapersonal and interpersonal religiosity) on only one of the dimensions in the tax compliance inventory, namely voluntary tax compliance, which underlies taxpayers' behavioral intentions. In short, a significant positive influence of religiosity on tax compliance in prior research is solely based on general religious commitment. Thus, there is insufficient understanding on which religious commitment dimension has a real impact on tax compliance.

Moreover, religiosity has a minimal, but significant, positive impact on taxpayers' attitudes. Therefore, general religiosity explains approximately only $5 \%$ of taxpayers' willingness to comply with tax laws and only $4 \%$ of their enforced tax compliance attitudes (Benk et al. 2016). These findings support the causal relationships between religion and tax compliance. Religious belief is expected to provide an internal control for an individual to clearly distinguish between good and bad behavior. However, the limited study on the influence of religiosity on tax compliance was mainly conducted in developed countries using secondary data (Benk et al. 2016).

Additionally, Gupta and McGee (2010) studied the effect of religion on tax evasion perceptions in Australasia. In an Australian study, Buddhists were significantly less opposed to tax evasion than Roman Catholics, Protestants, or Orthodox Christians. Roman Catholics were significantly less opposed to tax evasion than Protestants. Differences in mean scores for other comparisons of religion were not statistically significant. Ross and McGee (2011a) studied the effect of religion and sociodemographic variables on tax evasion in Malaysia. They found that Protestants were most opposed to tax evasion, followed by Roman Catholics, Muslims, Hindus, and Buddhists. In addition, those who were in the middle of the "God is important" statement spectrum were least opposed to tax evasion. Ross and McGee (2011b) also studied attitudes toward tax evasion in Switzerland. They found that respondents in the "Other" category, which presumably included atheists and agnostics, were most opposed to tax evasion, followed by Protestants, Roman Catholics, and Muslims.

The most straightforward impact might be based on whether a respondent believes in God. On the other hand, one can claim that belief in God might not be as important for a person to influence his or her behavior (Strielkowski and Čábelková 2015). For this reason, we include both the variable indicating the belief and the variable indicating how important God is in one's life. Another critique of these indicators might be the idea that what is important in religiosity is not only in how one believes, but also in what one does. We therefore included a variable to map how often one attends religious 
services. This variable is also important in that one may suggest that the morality of the respondent is influenced to a large extent by the community to which one belongs and might be reinforced by the information one gets from the priest.

\section{Research Methodologies and Data}

\subsection{Research Methodologies}

In many studies on taxpayer's perceptions of a concept, discrete models have been used to pose factors affecting the perception level. Since the perception data are categorical in nature, some studies have relied on logistic regression, while others have used multinomial or nested logit models (Rifaat and Chin 2007). The main analytical subject of this study is the exchange, horizontal, and vertical equity, where the exchange and horizontal equity are 5-level ordinal scales whereas the vertical equity is 4-level non-ordinal scales, composed of a baseline level and qualitatively different three other levels. Therefore, we apply the multinomial logit model in the analysis of vertical equity and the ordered probit model in the analysis of exchange and horizontal equity.

Recognizing that the discrete perception of tax equity is ordinal in nature, some studies have considered the ordered probit (OP) model to be more suitable. This choice lies in the assumption of the distribution of errors (Rifaat and Chin 2007; Renski et al. 1999). The ordered logit model is based on the assumption that the errors are independently and identically distributed with the logistic distribution whereas the OP model is based on the assumption that the distribution of errors is a multivariate normal distribution. However, the results from the OP can be fairly similar to that of the ordered logit model (O’Donnel and Connor 1996).

Hence, the OP was suitable for use in this study and was therefore employed. The theoretical framework of the OP model, including the modeling, process, and method of evaluation, has been discussed thoroughly in many studies (Rifaat and Chin 2007). The general specifications and processes are described below.

The perception levels of tax equity are classified into different proportion categories in terms of respondent levels (Kim and Yoon 2017) (i.e., 1: Very low, 2: Generally low, 3: Adequate, 4: Generally high, and 5: Very high; however, in case of vertical equity, the classification is composed of a baseline level and qualitatively different three other levels, 0 : "It is an equitable system that reflects income level," 1: "It favors high-income earners," or 1: "It favors middle-income earners," and 1: "It favors low-income earners."). These categories are typically considered as ordinal outcomes (i.e., from very low (1) tax equity to very high). Ordered discrete choice models are generally used to analyze such ordinal response data. Among these models, the OP is the most commonly used approach (Anarkooli et al. 2017). Let us assume that $\mathrm{y}_{n i}$ is the perception level of tax equity, $n$, by respondent $i$. The OP model assumes that the perception level can be represented by a latent and continuous variable, $\left(\mathrm{y}_{n i}{ }^{*}\right)$, which is related to $\mathrm{X}_{n i}$ given as:

$$
\mathrm{y}_{n i}^{*}=\mathrm{X}_{n i} \beta+\varepsilon_{n i} \forall_{i}
$$

where $X_{n i}$ is a vector of explanatory variables (religiosity, religion, or other control variables), $\beta$ is a vector of unknown parameters to be estimated, and $\varepsilon_{n i}$ is the random error term capturing the effect of unobserved factors, which is assumed to follow a normal distribution with a zero mean and unit variance (Anarkooli et al. 2017).

In the respondent's survey panel data presented in this study, the perception levels of religiosity or religion are scaled to 2 levels: dummy variable 0 or 1 . The dependent variables (i.e., exchange equity and horizontal equity) are then ordered based on several categories. For the taxpayer's perception level, $n$, to occur from respondent $i$, the observed perception level, $\left(\mathrm{y}_{n i}\right)$, is related to an unobserved (latent) variable, $\left(\mathrm{y}_{n i}{ }^{*}\right)$, and is expressed as follows: 


$$
\mathrm{y}_{n i}=j \Rightarrow \mu_{j-1} \leq \mathrm{y}_{n i}^{*} \leq \mu_{j} \Leftrightarrow\left(\begin{array}{l}
1 \text { if } \mathrm{y}_{n i}^{*}=\text { "Very low"exchange or horizental equity } \\
2 \text { if } \mathrm{y}_{n i}^{*}=\text { "Generally low"exchange or horizental equity } \\
3 \text { if } \mathrm{y}_{n i}^{*}=\text { "Adequate"exchange or horizental equity } \\
4 \text { if } \mathrm{y}_{n i}^{*}=\text { Generally high exchange or horizental equity } \\
5 \text { if } \mathrm{y}_{n i}^{*}=\text { "Very high"exchange or horizental equity }
\end{array}\right.
$$

where $j$ is the number of taxpayers' perception levels (in this case, $j=5$ ); and $\mu_{1}, \mu_{2}, \mu_{3}, \mu_{4}$, and $\mu_{5}$ are unknown threshold parameters to be estimated. The predicted probabilities of the perception level, $j(j=1,2,3,4,5)$, can be estimated as:

$$
\mathrm{P}\left(\mathrm{Y}_{n i}=j\right)=\mathrm{F}\left(\mu_{j}-\mathrm{X}_{n i}^{\prime} \beta\right)-\mathrm{F}\left(\mu_{j-1}-\mathrm{X}_{n i}^{\prime} \beta\right)
$$

where $\mathrm{F}(\cdot)$ is the standard normal cumulative distribution function. The model parameters (e.g., $\beta$ and $\mathrm{y}_{n i}{ }^{*}$ ) are estimated by the method of maximum likelihood. The marginal effects of the OP model with respect to explanatory variable $l,\left(\beta_{l}\right)$, can be estimated as:

$$
\mathrm{ME}_{J l \mid X l}=\frac{\partial \mathrm{P}\left(\mathrm{Y}_{n l}=j \mid \mathrm{X}_{n i}\right)}{\partial X_{I l}}=\left[f\left(\mu_{j-1}-\mathrm{X}_{n i}^{\prime} \beta\right)-f\left(\mu_{j}-\mathrm{X}_{n i}^{\prime} \beta\right)\right] \cdot \beta_{l}
$$

where $f(\cdot)$ is the density function.

Porcano (1985) asserts that from an equity perspective, taxpayers' need and ability to pay are the most significant factors that determine their perceptions of equitable tax structures. We include demographic variables in the models that can capture the taxpayers' need and ability to pay, such as a household's income level, income source, assets, consumption expenditure, number of dependents, house ownership and region. Additionally, the models also include a respondent's marital status, age, education, and gender as independent variables to confirm the group's diversity in equity perceptions.

A progressive tax system is unfavorable for high-income taxpayers with respect to exchange inequity because higher-income taxpayers face a higher marginal tax rate. They get no more benefits than lower-income taxpayers. Therefore, it is posited that they will perceive the exchange relationship with the government as more inequitable. Taxpayers in higher tax brackets gain more by evading (Porcano 1988) and, thus, if presented with opportunities to cheat, are more tempted to engage in tax noncompliance to reduce their tax dues. They are likely to judge the tax system as less favorable, compared to others in a similar income group because they are expected to be susceptible to a self-serving bias. Likewise, they will evaluate the tax system as more favorable to lower-income earners.

Those who are self-employed with business income would perceive taxpaying as more painful, considering the amount of time and effort involved (Kamleitner et al. 2012). Hence, they will reveal more negative attitudes toward exchange equity. Moreover, they have more opportunities to hide income that is not subject to third-party reporting. If they take this fact into consideration, they will evaluate the tax system as more favorable to them in terms of horizontal equity. Alternatively, if they believe much time and effort is required to earn their income, they will perceive taxpaying as a more painful loss and, thus, perceive the tax system as horizontally inequitable. This parallels studies on income source and tax behaviors, which suggest the amount of time and effort required to generate income affects compliance (Boylan and Sprinkle 2001). With income level and income source, we consider other demographic variables of interest that can capture different taxpayer categories. The multinomial logit model in the analysis of vertical equity (three cases of simple logit model) and the ordered probit model in the analysis of exchange (horizontal equity (Equation (2)) are applied. The regression models are illustrated in the following equations:

$$
\begin{aligned}
\text { ExchEq } & =\beta_{0}+\beta_{1} \text { RELIGIOSITY }(\text { RELIGION })+\beta_{2} \text { HIGH }+\beta_{3} B I Z+\beta_{4} \text { ASSET } \\
& +\beta_{5} \text { CONSUME }+\beta_{6} D E P+\beta_{7} \text { HOUSE }+\beta_{8} M A R+\beta_{9} A G E \\
& +\beta_{10} \text { EDU }+\beta_{11} \text { GENDER }+\beta_{12} \text { METRO }+\varepsilon
\end{aligned}
$$




$$
\begin{aligned}
\text { HorizEq } & =\beta_{0}+\beta_{1} \text { RELIGIOSITY }(\text { RELIGION })+\beta_{2} \text { HIGH }+\beta_{3} \text { BIZ }+\beta_{4} \text { ASSET } \\
& +\beta_{5} \text { CONSUME }+\beta_{6} \text { DEP }+\beta_{7} \text { HOUSE }+\beta_{8} M A R+\beta_{9} \text { AGE } \\
& +\beta_{10} \text { EDU }+\beta_{11} \text { GENDER }+\beta_{12} \text { METRO }+\varepsilon, \\
\text { VertEq } & =\beta_{0}+\beta_{1} \text { RELIGIOSITY }(\text { RELIGION })+\beta_{2} H I G H+\beta_{3} B I Z+\beta_{4} \text { ASSET } \\
& +\beta_{5} \text { CONSUME }+\beta_{6} \text { DEP }+\beta_{7} \text { HOUSE }+\beta_{8} M A R+\beta_{9} \text { AGE } \\
& +\beta_{10} \text { EDU }+\beta_{11} \text { GENDER }+\beta_{12} \text { METRO }+\varepsilon,
\end{aligned}
$$

where,

ExchEq: Exchange equity denotes the five-point scale for the question, "What do you think of the benefits from the government compared to the tax you paid?" as follows: 1-“Very low," 2-“Generally low," 3-“Adequate," 4-“Generally high," and 5-“Very high."

HorizEq: Horizontal equity denotes the five-point scale for the question, "What do you think of your tax burden compared to that of counterparts with similar incomes?" as follows: 1- "Very high," 2-“Generally high," 3-“Adequate," 4-“Generally low," and 5-“Very low".

VertEq: Vertical equity denotes the answers to the question, "What do you think of the current tax system?" as follows: 1-“It is an equitable system that reflects income level," 2-"It favors

\begin{tabular}{|c|c|c|c|c|}
\hline & & $\begin{array}{c}\text { High-Incomers } \\
\text { Favorable: It Favors } \\
\text { High-Income Earners }\end{array}$ & $\begin{array}{l}\text { Middle-Incomers } \\
\text { Favorable: It Favors } \\
\text { Middle-Income Earners }\end{array}$ & $\begin{array}{c}\text { Low-Incomers } \\
\text { Favorable: It Favors } \\
\text { Low-Income Earners }\end{array}$ \\
\hline & & 1 & 1 & 1 \\
\hline $\begin{array}{l}\text { Neutral: It is an } \\
\text { equitable system that } \\
\text { reflects income level }\end{array}$ & 0 & {$[0,1]$} & {$[0,1]$} & {$[0,1]$} \\
\hline
\end{tabular}
high-income earners," 3- "It favors middle-income earners," and 4-“It favors low-income earners". This questionnaire consists of multinomial variables ranging from 1 to 4 , but in the analysis of this study, there are three cases: neutral versus high-incomers favorable, neutral versus middle-incomers favorable, and neutral versus low-incomers favorable. See Table 1.

Table 1. Measurement of vertical equity variable: Binary scale.

RELIGIOSITY: 1 if a household follows a religion; 0 otherwise.

RELIGION: It is classified as Protestant, Catholic, and Buddhist. In Korea, Catholicism does not oppose the introduction of clergy taxation, while Protestantism or Buddhism strongly opposes the implementation of this. Catholicism recognizes that it is natural that taxes are paid to the state, and that the priesthood activities of the clergy are also labor and taxable. Therefore, it is assumed that the effects of individual religions on tax equity will be different.

HIGH: 1 if a respondent's income is more than 40 million KRW; 0 otherwise. One USD is approximately equivalent to $1,100 \mathrm{KRW}$ in our sample period.

BIZ: 1 if a household has business income; 0 otherwise.

ASSET: Natural log of the net asset per household (10,000 KRW).

CONSUME: Natural log of consumption expenditure per household (10,000 KRW).

DEP: Number of dependents per household.

HOUSE: 1 if residing house is self-owned; 0 otherwise.

MAR: 1 if a respondent is married; 0 otherwise.

AGE: 1 if a respondent is older than 40 years; 0 otherwise.

EDU: 1 if a respondent's educational level is college degree or higher; 0 otherwise.

GENDER: 1 if a respondent is female; 0 otherwise.

METRO: 1 if a household resides in the Seoul metropolitan region; 0 otherwise. 


\subsection{Data}

This study's empirical analysis is based on a financial panel survey conducted by the Korea Institute of Public Finance (hereafter referred to as "KIPF" occasionally) in 2017. This finance panel survey has targeted households and their members since 2008 to analyze the policy effects of the tax system's revision. The survey data on taxpayers' various traits in the previous year has been published in the following year annually since 2009. This study's data was obtained by investigating household members' attitudes toward the tax system. As the survey subject, this survey defined the general households and their members who live in 15 provinces except Jeju Island in Korea as the population. The sampling frame for extracting sample households used $90 \%$ data provided by the National Statistical Office to the external statistical agency in 2005 (KIPF 2017). In addition, if the number of samples grows excessively, the non-sampling error occurring in the review process due to unreasonable survey progress can be rather large. Non-sample errors are often caused by the process of on-the-spot investigation, such as false answers of respondents, non-response or selection bias of interviewers, and unfaithful attitudes. So, it is very important to determine the appropriate sample size considering the purpose and circumstances of the investigation. The sampling unit of this survey is the primary sampling unit used in the Population and Housing Census, and the two-stage cluster sampling method was used to extract a certain number of households from the surveyed area. Therefore, the sample of this study is the credible data used by the Korean government, and it is very representative of the Korean people.

\section{Results}

\subsection{Descriptive Statistics and Correlation Analysis}

Table 2 shows the perceived tax equity and the metrics of religion. The total distribution of 104,913 respondents comprises 16,712 Protestants (15.9\%), 4,552 Catholic (4.3\%), 17,677 Buddhists (16.8\%), and 65,972 atheists or nonreligious people (62.9\%). Regarding exchange equity, $42.2 \%$ recognized that it was "Adequate," while 32.0\% recognized that it was "Generally high"; $53.8 \%$ perceived horizontal equity to be "Adequate" and 34.3\% perceived it to be "Generally low." As for vertical equity, $57.4 \%$ of respondents perceived the current tax system as "favorable for high-incomers." These results indicate that respondents generally perceive the tax system to be appropriate, with neither exchange nor horizontal equity being high or low; however, they have somewhat negative perceptions of vertical equity.

Table 2. Distribution of perceived equity by each religion.

\begin{tabular}{|c|c|c|c|c|c|c|c|}
\hline \multirow{2}{*}{ Proxy } & \multirow{2}{*}{ Question } & \multirow{2}{*}{ Answer } & \multicolumn{5}{|c|}{ Frequency } \\
\hline & & & Protestant & Catholic & Buddhism & No Religion & Totals \\
\hline \multirow{6}{*}{$\begin{array}{l}\text { Perceived } \\
\text { exchange } \\
\text { equity }\end{array}$} & \multirow{6}{*}{$\begin{array}{l}\text { Perception on } \\
\text { government } \\
\text { benefits } \\
\text { compared with } \\
\text { tax payment }\end{array}$} & Very low & 710 & 227 & 565 & 2496 & 3998 \\
\hline & & Generally low & 1979 & 538 & 1926 & 7893 & 12,336 \\
\hline & & Adequate & 2618 & 756 & 2973 & 9911 & 16,258 \\
\hline & & Generally high & 815 & 176 & 973 & 3678 & 5642 \\
\hline & & Very high & 57 & 12 & 45 & 195 & 309 \\
\hline & & Totals & 6179 & 1709 & 6482 & 24,173 & 38,543 \\
\hline \multirow{6}{*}{$\begin{array}{c}\text { Perceived } \\
\text { horizontal } \\
\text { equity }\end{array}$} & \multirow{6}{*}{$\begin{array}{l}\text { Tax payment } \\
\text { compared with } \\
\text { taxpayer groups } \\
\text { with similar } \\
\text { levels of income }\end{array}$} & Very low & 130 & 34 & 102 & 455 & 721 \\
\hline & & Generally low & 404 & 122 & 425 & 1556 & 2507 \\
\hline & & Adequate & 3387 & 926 & 3587 & 12,828 & 20,728 \\
\hline & & Generally high & 2008 & 545 & 2170 & 8495 & 13,218 \\
\hline & & Very high & 250 & 82 & 198 & 840 & 1370 \\
\hline & & Totals & 6179 & 1709 & 6482 & 24,174 & 38,544 \\
\hline \multirow{5}{*}{$\begin{array}{l}\text { Perceived } \\
\text { vertical } \\
\text { equity }\end{array}$} & \multirow{5}{*}{$\begin{array}{l}\text { Opinion on } \\
\text { current tax } \\
\text { system: }\end{array}$} & An equitable system & 1091 & 293 & 1072 & 4112 & 6568 \\
\hline & & $\begin{array}{l}\text { Favorable for } \\
\text { high-incomers. }\end{array}$ & 2520 & 639 & 2673 & 10,132 & 15,964 \\
\hline & & $\begin{array}{l}\text { Favorable for } \\
\text { middle- incomers. }\end{array}$ & 494 & 102 & 720 & 2508 & 3824 \\
\hline & & $\begin{array}{l}\text { Favorable for } \\
\text { low-incomers. }\end{array}$ & 249 & 100 & 248 & 873 & 1470 \\
\hline & & Totals & 4354 & 1134 & 4713 & 17,625 & 27,826 \\
\hline
\end{tabular}


Table 3 illustrates the variables' descriptive statistics. The respondents, on average, perceived the exchange and horizontal equities as inadequate and generally low, respectively. The mean of vertical equity, 2.007, implies that that the "current tax system favors the high-incomers." Less than $20 \%$ (or $18.8 \%$ ) of the population belonged to a high income group, with an income of more than KRW 40 million. The sample comprised $27.6 \%$ of business income earners. The descriptive statistics of the remaining variables are shown in Table 3.

Table 3. Descriptive statistics.

\begin{tabular}{cccccccc}
\hline & Mean & St. Dev & MIN & Q1 & Med & Q3 & MAX \\
\hline ExchEq & 2.635 & 0.883 & 1 & 2 & 3 & 3 & 5 \\
HorizEq & 2.688 & 0.727 & 1 & 2 & 3 & 3 & 5 \\
VertEq & 2.007 & 0.765 & 1 & 2 & 2 & 2 & 4 \\
HIGH & 0.188 & 0.391 & 0 & 0 & 0 & 0 & 1 \\
BIZ & 0.276 & 0.447 & 0 & 0 & 0 & 1 & 1 \\
ASSET & 9.413 & 1.905 & 0 & 8.889 & 9.749 & 10.436 & 14.534 \\
CONSUME & 7.904 & 0.868 & 1.792 & 7.361 & 8.062 & 8.533 & 11.545 \\
DEP & 1.171 & 1.356 & 0 & 0 & 1 & 2 & 7 \\
HOUSE & 0.652 & 0.476 & 0 & 0 & 1 & 1 & 1 \\
MAR & 0.636 & 0.481 & 0 & 0 & 1 & 1 & 1 \\
AGE & 0.743 & 0.437 & 0 & 0 & 1 & 1 & 1 \\
EDU & 0.273 & 0.445 & 0 & 0 & 0 & 1 & 1 \\
GENDER & 0.428 & 0.495 & 0 & 0 & 0 & 1 & 1 \\
METRO & 0.296 & 0.457 & 0 & 0 & 0 & 1 & 1 \\
\hline
\end{tabular}

\subsection{The Relationship between Religiosity (Religion) and Perceptions of Exchange and Horizontal Equities}

Table 4 presents the estimated coefficients of the independent variables affecting exchange and horizontal equities, through a random-effect OP regression. First, RELIGIOSITY represents a positive coefficient, not with a statistically significant level. This result implies that religious beliefs have statistically insignificant impact on exchange and horizontal equities. The result also shows that that religiosity or religion is different based on prior studies argue that tax morale rises by lowering tax avoidance and that tax equity is not related to religiosity (Benk et al. 2016; Mohdali and Pope 2014; Worthington et al. 2003). This indirectly indicates that religiosity is not directly linked to tax equity, but leads directly to tax avoidance or tax morale. Furthermore, the results of nested models tests show that no significant increase in explanatory power of RELIGIOSITY happens for each dependent variable (LR chi-square values are $0.37(p<0.5443)$ and $2.64(p<0.1042))$, respectively, while untabulated results of the test of homogeneity show that the distributions of each dependent variable are significantly far from being equivalent according to the value of RELIGIOSITY.

In addition, estimated coefficients for HIGH are $-0.072(p<0.1)$ and $-0.395(p<0.001)$, which are statistically significant for exchange equity and horizontal equity, respectively, indicating that exchange equity and horizontal equity are negatively associated with higher income levels. The estimated coefficient of BIZ for exchange equity is $-0.094(p<0.001)$, indicating that respondents who run businesses, such as sole proprietorships, hold a negative view of exchange equity. Regression results of other variables are shown in Table 4.

Prior studies indicate that demographic factors, such as age, gender, and education, correlate with tax morale (Kornhauser 2009). Age and gender, despite being statistically weak, have a positive impact on horizontal equity perceptions. Generally, having knowledge of tax laws and fiscal policies can enhance positive attitudes toward taxes. However, this result clearly means that highly educated taxpayers in Korea perceive the current tax system as less equitable in terms of both exchange and horizontal equities. This implies that higher education is incapable of providing adequate tax knowledge; therefore, tax authorities should develop educational programs to mitigate negative attitudes toward tax. 
Table 4. The effect of religiosity on perceptions of exchange and horizontal equities.

\begin{tabular}{|c|c|c|c|c|c|c|}
\hline \multirow{2}{*}{ Variable } & \multicolumn{3}{|c|}{ Exchange Equity } & \multicolumn{3}{|c|}{ Horizontal Equity } \\
\hline & \multicolumn{2}{|c|}{ Estimate } & \multirow{2}{*}{$\begin{array}{c}\text { Std. Error } \\
0.034\end{array}$} & \multicolumn{2}{|c|}{ Estimate } & \multirow{2}{*}{$\begin{array}{c}\text { Std. Error } \\
0.030\end{array}$} \\
\hline RELIGIOSITY & 0.020 & & & 0.049 & & \\
\hline HIGH & -0.072 & * & 0.039 & -0.395 & $* * *$ & 0.038 \\
\hline BIZ & -0.094 & $* * *$ & 0.033 & -0.034 & & 0.031 \\
\hline ASSET & 0.000 & & 0.009 & -0.041 & $* * *$ & 0.009 \\
\hline CONSUME & -0.171 & $* * *$ & 0.022 & -0.305 & $* * *$ & 0.020 \\
\hline DEP & 0.048 & $* * *$ & 0.015 & -0.010 & & 0.014 \\
\hline HOUSE & -0.003 & & 0.034 & -0.058 & * & 0.032 \\
\hline MAR & -0.145 & $* * *$ & 0.026 & -0.204 & $* * *$ & 0.026 \\
\hline AGE & 0.005 & & 0.037 & 0.163 & $* * *$ & 0.034 \\
\hline EDU & -0.096 & $* *$ & 0.043 & -0.175 & $* * *$ & 0.037 \\
\hline GENDER & 0.109 & $* * *$ & 0.043 & 0.058 & & 0.038 \\
\hline METRO & -0.681 & $* * *$ & 0.039 & 0.267 & $* * *$ & 0.034 \\
\hline Log Likelihood & \multicolumn{3}{|c|}{$-46,386.226$} & \multicolumn{3}{|c|}{$-39,280.508$} \\
\hline $\begin{array}{l}\text { Number of Obs. } \\
\text { LR chi-square }\end{array}$ & \multicolumn{3}{|c|}{38,543} & \multicolumn{3}{|c|}{38,544} \\
\hline $\begin{array}{l}\text { (nested model test } \\
\text { for RELIGIOSITY) }\end{array}$ & \multicolumn{3}{|c|}{0.37} & \multicolumn{3}{|c|}{2.64} \\
\hline Chi-square & \multicolumn{3}{|c|}{$44.82 * * *$} & \multicolumn{3}{|c|}{$21.36^{* * *}$} \\
\hline
\end{tabular}

Table 5 shows the results of the analysis on the effect of each religion on exchange or horizontal equity. Regarding horizontal equity, PROTESTANT shows a statistically significant coefficient of $0.08(p<0.1)$, which means that the respondents are more likely to recognize the horizontal equity positively if they are a Protestant. However, CATHOLIC and BUDDHISM do not show statistically significant coefficients. Thus, unlike prior studies, the effect of religion on exchange or horizontal equity is not uniformly significant, suggesting that only Protestantism has a slightly positive effect. The coefficients of HIGH are $-0.071(p<0.1)$ and $-0.394(p<0.001)$, indicating negative attitudes toward exchange and horizontal equities, respectively. CONSUME also shows estimated coefficients of $-0.172(p<0.001)$ and $-0.307(p<0.001)$ at the statistically significant level, and the coefficients of MAR are $-0.145(p<0.001)$ and $-0.203(p<0.001)$ for exchange and horizontal equities, respectively. Thus, the regression results implies that both having a higher level of consumption and getting married have a negative influence on the perception of exchange and horizontal equities.

Table 5. The effect of religion on perceptions of exchange and horizontal equities.

\begin{tabular}{|c|c|c|c|c|c|c|}
\hline \multirow{3}{*}{$\begin{array}{c}\text { Variable } \\
\text { PROTESTANT }\end{array}$} & \multicolumn{3}{|c|}{ Exchange Equity } & \multicolumn{3}{|c|}{ Horizontal Equity } \\
\hline & \multicolumn{2}{|c|}{ Estimate } & \multirow{2}{*}{$\begin{array}{c}\text { Std. Error } \\
0.046\end{array}$} & \multicolumn{2}{|c|}{ Estimate } & \multirow{2}{*}{$\begin{array}{c}\text { Std. Error } \\
0.041\end{array}$} \\
\hline & 0.016 & & & 0.080 & * & \\
\hline CATHOLIC & 0.123 & & 0.079 & 0.097 & & 0.071 \\
\hline BUDDHISM & -0.003 & & 0.045 & 0.007 & & 0.040 \\
\hline HIGH & -0.071 & $*$ & 0.040 & -0.394 & $* * *$ & 0.038 \\
\hline BIZ & -0.093 & $* * *$ & 0.033 & -0.033 & & 0.031 \\
\hline ASSET & 0.000 & & 0.009 & -0.040 & $* * *$ & 0.009 \\
\hline CONSUME & -0.172 & $* * *$ & 0.022 & -0.307 & $* * *$ & 0.020 \\
\hline DEP & 0.048 & $* * *$ & 0.015 & -0.010 & & 0.014 \\
\hline HOUSE & -0.004 & & 0.034 & -0.058 & * & 0.032 \\
\hline MAR & -0.145 & $* * *$ & 0.026 & -0.203 & $* * *$ & 0.026 \\
\hline AGE & 0.004 & & 0.037 & 0.163 & $* * *$ & 0.034 \\
\hline EDU & -0.100 & $* *$ & 0.043 & -0.180 & $* * *$ & 0.038 \\
\hline GENDER & 0.109 & $* *$ & 0.043 & 0.057 & & 0.038 \\
\hline METRO & -0.691 & $* * *$ & 0.040 & 0.256 & $* * *$ & 0.034 \\
\hline Log Likelihood & & 5,385 & & & 280. & \\
\hline Number of Obs. & & 38,54 & & & 8,544 & \\
\hline
\end{tabular}

Note: ${ }^{*}, * *$ and ${ }^{* * *}$ indicate significance at the $10 \%, 5 \%$, and $1 \%$ levels, respectively, for one-tailed test. 


\subsection{The Relationship between Religiosity (Religion) and Vertical Equity Perceptions}

Table 6 presents the coefficients of independent variables affecting vertical equity through the random-effect logistic regression. The logistic regression perceives independent variables' relative effects on one of the three inequity perceptions (e.g., high, middle, and low-incomers favorable), with reference to the baseline equity perception. Thus, compared to the base outcome- "It is an equitable system that reflects income level" - each column in the table represents the likelihood that independent variables will predict the tax system as more favorable for high-income earners (vertical inequity 2), for middle-income earners (vertical inequity 3), and for low-income earners (vertical inequity 4).

Table 6. The effect of religiosity on perceptions of vertical equity.

\begin{tabular}{|c|c|c|c|c|c|c|}
\hline \multirow[t]{2}{*}{ Variable } & \multicolumn{2}{|c|}{$\begin{array}{l}\text { Vertical Inequity1 } \\
\text { (High-Incomers) }\end{array}$} & \multicolumn{2}{|c|}{$\begin{array}{l}\text { Vertical Inequity2 } \\
\text { (Middle-Incomers) }\end{array}$} & \multicolumn{2}{|c|}{$\begin{array}{l}\text { Vertical Inequity3 } \\
\text { (Low-Incomers) }\end{array}$} \\
\hline & Estimate & Std. Error & Estimate & Std. Error & Estimate & Std. Error \\
\hline RELIGIOSITY & 0.021 & 0.032 & -0.028 & 0.051 & $0.154^{* * *}$ & 0.065 \\
\hline HIGH & $0.045^{* * *}$ & 0.045 & $-0.202^{* * *}$ & 0.070 & 0.175 & 0.085 \\
\hline BIZ & $0.035^{* * *}$ & 0.035 & 0.052 & 0.054 & 0.091 & 0.071 \\
\hline ASSET & $0.011^{* *}$ & 0.011 & -0.022 & 0.016 & 0.061 & 0.025 \\
\hline CONSUME & 0.024 & 0.024 & $-0.113^{* * *}$ & 0.037 & $0.089^{* * *}$ & 0.050 \\
\hline DEP & $0.016^{* * *}$ & 0.016 & $0.160 * * *$ & 0.024 & 0.081 & 0.031 \\
\hline HOUSE & $0.037^{* * *}$ & 0.037 & $0.148^{* * *}$ & 0.057 & -0.016 & 0.073 \\
\hline MAR & $0.035^{* * *}$ & 0.035 & $-0.312^{* * *}$ & 0.051 & -0.675 & 0.066 \\
\hline AGE & $0.038^{* * *}$ & 0.038 & $-0.385^{* * *}$ & 0.059 & $0.109^{* * *}$ & 0.078 \\
\hline EDU & 0.039 & 0.039 & -0.054 & 0.062 & 0.136 & 0.077 \\
\hline GENDER & $0.040 *$ & 0.040 & 0.015 & 0.063 & $0.016^{* * *}$ & 0.083 \\
\hline METRO & $0.036^{* * *}$ & 0.036 & $-0.844^{* * *}$ & 0.061 & $0.372^{* * *}$ & 0.069 \\
\hline $\begin{array}{c}\text { LR chi-square } \\
\text { (nested model test } \\
\text { for RELIGIOSITY) }\end{array}$ & \multicolumn{2}{|l|}{0.86} & \multicolumn{2}{|l|}{1.40} & $3.86^{* *}$ & \\
\hline Chi-square & \multirow{3}{*}{\multicolumn{2}{|c|}{1.48}} & \multirow{3}{*}{\multicolumn{2}{|c|}{$\begin{array}{c}9.28 * * * \\
-29,232.87 \\
27,826\end{array}$}} & $5.28 * *$ & \\
\hline Log Likelihood & & & & & & \\
\hline Number of Obs. & & & & & & \\
\hline
\end{tabular}

Note: $* * *$, and ${ }^{* * *}$ indicate significance at the $10 \%, 5 \%$, and $1 \%$ levels, respectively, for one-tailed test. Additionally, vertical inequity 1,2 , and 3 variables are defined as neutral versus high-incomers favorable $[0,1]$, neutrality versus middle-incomers favorable $[0,1]$, and neutrality versus low-incomers favorable, respectively.

First, the coefficients of RELIGIOSITY are statistically insignificant for the vertical inequity 2 (high) and 3 (middle) columns, but statistically significant at $0.154(p<0.001)$ for the vertical inequity 4 (low) column. Thus, it means that respondents perceive the current tax system in Korea favors low-income earners. These results support the findings that religiosity or religion affects vertical equity, unlike the insignificant effect of religiosity or religion on exchange and horizontal equity. Moreover, taxpayers who are wealthier, older, well-educated, and living inside the Seoul metropolitan areas are more likely to evaluate the tax system as equitable and, therefore, relatively more favorable to higher-income earners than to lower-income earners. Second, taxpayers who are less wealthy, unmarried, younger and poorly educated, and who have less expenditure, more dependents and a residing house are more likely to believe the tax system is relatively more favorable to middle-income earners than to believe that it is equitable. Finally, taxpayers who are highly educated, older, female and living in the Seoul metropolitan area are more likely to perceive the tax system as more favorable to lower-income earners than to judge it as equitable.

Similarly, the results of nested models tests, which are done under separate panel logit specification-for example, the test in the "Vertical inequity 2" column only uses sample data whose value of the perceived vertical equity is 0 (baseline) or 2 (high), shows that no significant increase in the explanatory power of RELIGIOSITY happens for Vertical inequity 2 and Vertical inequity 3 (LR chi-square values are $0.86(p<0.3539)$ and $1.40(p<0.2363))$, respectively, while a significant increase in the explanatory power of RELIGIOSITY happens for Vertical inequity 4 (LR chi-square 
value is $3.86(p<0.0494))$. Furthermore, the untabulated results of the test of homogeneity show that the distribution of Vertical inequity 2 is equivalent, while the distributions of Vertical inequity 3 and Vertical inequity 4 are significantly inequivalent according to the value of RELIGIOSITY.

Table 7 shows the results of analyzing the effect of each religion on vertical equity. It shows statistically significant results only for Vertical inequity 4 (low).

Table 7. The effect of religion on the perception of vertical equity.

\begin{tabular}{|c|c|c|c|c|c|c|c|c|c|}
\hline \multirow{3}{*}{$\begin{array}{c}\text { Variable } \\
\text { PROTESTANT }\end{array}$} & \multicolumn{3}{|c|}{$\begin{array}{l}\text { Vertical Inequity1 } \\
\text { (High-Incomers) }\end{array}$} & \multicolumn{3}{|c|}{$\begin{array}{l}\text { Vertical Inequity2 } \\
\text { (Middle-Incomers) }\end{array}$} & \multicolumn{3}{|c|}{$\begin{array}{l}\text { Vertical Inequity3 } \\
\text { (Low-Incomers) }\end{array}$} \\
\hline & \multicolumn{2}{|c|}{ Estimate } & \multirow{2}{*}{$\begin{array}{c}\text { Std. Error } \\
0.043\end{array}$} & \multicolumn{2}{|c|}{ Estimate } & \multirow{2}{*}{$\begin{array}{c}\text { Std. Error } \\
0.071\end{array}$} & \multicolumn{2}{|c|}{ Estimate } & \multirow{2}{*}{$\begin{array}{c}\text { Std. Error } \\
0.087\end{array}$} \\
\hline & 0.021 & & & -0.154 & $* *$ & & 0.002 & & \\
\hline CATHOLIC & 0.139 & * & 0.078 & -0.085 & & 0.136 & 0.276 & $* *$ & 0.138 \\
\hline BUDDHISM & -0.006 & & 0.043 & 0.081 & & 0.066 & 0.264 & $* * *$ & 0.088 \\
\hline HIGH & -0.140 & $* * *$ & 0.045 & -0.204 & $* * *$ & 0.070 & 0.172 & $* *$ & 0.085 \\
\hline BIZ & 0.093 & $* * *$ & 0.035 & 0.049 & & 0.054 & 0.089 & & 0.071 \\
\hline ASSET & -0.025 & $* *$ & 0.011 & -0.024 & & 0.016 & 0.057 & $* *$ & 0.025 \\
\hline CONSUME & 0.026 & & 0.024 & -0.108 & $* * *$ & 0.037 & 0.095 & $*$ & 0.050 \\
\hline DEP & 0.116 & $* * *$ & 0.016 & 0.162 & $* * *$ & 0.024 & 0.084 & $* * *$ & 0.031 \\
\hline HOUSE & 0.111 & $* * *$ & 0.037 & 0.149 & $* * *$ & 0.057 & -0.017 & & 0.073 \\
\hline MAR & -0.609 & $* * *$ & 0.035 & -0.313 & $* * *$ & 0.051 & -0.677 & $* * *$ & 0.066 \\
\hline AGE & -0.168 & $* * *$ & 0.038 & -0.389 & $* * *$ & 0.059 & 0.103 & & 0.078 \\
\hline EDU & 0.001 & & 0.039 & -0.038 & & 0.063 & 0.149 & $*$ & 0.078 \\
\hline GENDER & -0.079 & $* *$ & 0.040 & 0.019 & & 0.063 & 0.022 & & 0.083 \\
\hline METRO & -0.487 & $* * *$ & 0.037 & -0.817 & $* * *$ & 0.063 & 0.388 & $* * *$ & 0.071 \\
\hline Log Likelihood & \multicolumn{9}{|c|}{$-29,224.639$} \\
\hline Number of Obs. & \multicolumn{9}{|c|}{27,826} \\
\hline
\end{tabular}

First, in the Vertical inequity 2 column, only the coefficient of CATHOLIC is statistically significant at $0.139(p<0.1)$, which indicates that Catholic respondents are more likely to recognize that the tax system is more favorable for high-income earners. In addition, those who are younger and wealthier, and who have lower income, more dependents, and who runs his/her own business, have a negative perception of vertical equity.

Second, in the Vertical inequity 3 column, only the coefficient of PROTESTANT is statistically significant at $-0.154(p<0.05)$, which means that the Protestant respondents are likely to perceive that the tax system is more favorable for middle-income earners. Furthermore, those who are older, and who have higher income, higher consumption, more dependents, are more likely to perceive that the vertical equity for middle-income earners is relatively good.

Third, regarding the Vertical inequity 4 column, PROTETANT is not statistically significant while CATHOLIC and BUDDHISM are significant at $0.276(p<0.05)$ and $0.264(p<0.001)$, respectively. This result implies that the Catholic and Buddhist respondents are more likely to perceive that the current tax system is more favorable for low-income earners. For other explanatory variables, those who are less wealthy, and who have lower income, more dependents, and who reside in the Seoul metropolitan region, are more likely to perceive that vertical equity for low-income earners is relatively poor.

\section{Conclusions}

The aim of this study was to investigate the link between taxpayers' religiosity, religion, and tax equity, including exchange, horizontal, and vertical equities. Prior studies argue that religiosity and religion affect tax evasion or tax morale. However, in Korea, there had been a debate about the clergy taxation before implementation in 2018, there is still a weak consensus in each religious and political community (Kim 2008; Song and Kim 2008; Lee 2011; Choi and Suh 2015). Therefore, this study intends 
to prove that the relationship between religion and tax equity is different from that mentioned in prior literature.

The results of this study can be summarized as follows.

First, taxpayers' religiosity shows a statistically insignificant relationship with exchange and horizontal equity. This is inconsistent with the findings of prior studies, which showed that religiosity or religions are related to tax evasion. However, this result can be interpreted to mean that religion does not play a mediating role in the relationship between behavioral tax evasion and psychological exchange and horizontal equities. In particular, economic status variables-such as income, assets, consumption, and house ownership-and demographic variables have a statistically significant relationship with exchange or horizontal equity. This result implies that taxpayers' tax evasion can be caused by either economic or social incentives rather than by religion. On the other hand, taxpayers' religiosity shows a statistically significant relationship with vertical equity. In other words, taxpayers who follow a religion perceive the current tax system as being favorable to low-income earners, showing a negative perception of vertical equity.

Second, the relationship between religion and exchange or horizontal equity of taxpayers was statistically insignificant. Therefore, there is no difference in taxpayers' perceptions of exchange or horizontal equity according to religion. In contrast, Catholicism and Buddhism have statistically significant effects on vertical equity. That is, Catholic respondents perceive the current tax system as being favorable to high- and low-income earners, while Buddhist taxpayers perceive the current tax system as being favorable to low-income earners.

Third, taxpayers' economic features, such as income, assets and consumption, and demographic characteristics, such as number of dependents, age, marital status, home ownership and residential location, affect their perception of tax equity. This supports the results of prior studies and implies that economic and social incentives exist to determine tax evasion or tax morale.

This study can be contributive to provide important insights into the relationship between taxpayers' various characteristics and tax morale in that perceived equity may mediate or moderate their compliance behaviors.

Author Contributions: All authors participated in designing and writing the experiments, and performed the experiments and analyzed the data.

Funding: This research received no external funding.

Conflicts of Interest: The authors declare no conflicts of interest.

\section{References}

Adams, J. Stacy. 1965. Inequity in social exchange. Advances in Experimental Social Psychology 2: 267-99.

Allingham, Michael G., and Agnar Sandmo. 1972. Income tax evasion: A theoretical analysis. Journal of Public Economics 1: 323-38. [CrossRef]

Alm, James, Gary H. McClell, and William D. Schulze. 1992. Why do people pay taxes? Journal of Public Economics 48: 21-38. [CrossRef]

Alm, James, and Benno Torgler. 2011. Do Ethics Matter? Tax Compliance and Morality. Journal of Business Ethics 101: 635-51. [CrossRef]

Anarkooli, Alireza Jafari, Mehdi Hosseinpour, and Adele Kardar. 2017. Investigation of factors affecting the injury severity of single-vehicle rollover crashes: a random-effects generalized ordered probit model. Accident Analysis Prevention 106: 399-410.

Becker, Gary S. 1968. Crime and Punishment: An Economic Approach. Journal of Public Economics 76: 169-217.

Benk, Serkan Benk, Tamer Budak, Bahadır Yüzbaşı, and Raihana Mohdali. 2016. The Impact of Religiosity on Tax Compliance among Turkish Self-Employed Taxpayers. Religions 7: 37. [CrossRef]

Bordignon, Massimo. 1993. A equity approach to income tax evasion. Journal of Public Economics 52: 345-62. [CrossRef]

Boylan, Scott J., and Geoffrey B. Sprinkle. 2001. Experimental evidence on the relation between tax rates and compliance: The effect of earned vs. endowed income. Journal of the American Taxation Association 23: 75-90. [CrossRef] 
Choi, Byeong Gon, and Hi Youl Suh. 2015. A Study on Taxation System of Religious Organization and Religious Man. Korean Journal of Tax Studies 15: 95-130. (In Korean)

Cowell, Frank A. 1992. Tax evasion and inequity. Journal of Economic Psychology 13: 521-43. [CrossRef]

Feld, Lars P., and Bruno S. Frey. 2002. Trust breeds trust: How taxpayers are treated. Economics of Governance 3: 87-99. [CrossRef]

Frey, Bruno S. 1997. A constitution for knaves crowds out civic virtues. The Economic Journal 107: $1043-53$. [CrossRef]

Frey, Bruno S., and Lars P. Feld. 2002. Deterrence and Morale in Taxation: An Empirical Analysis. Working paper No. 760. Basel, Switzerland: CESifo, August.

Gupta, Ranjana, and Robert McGee. 2010. Study on Tax Evasion Perceptions in Australasia. Australian Tax Forum 25: 507-34.

Hessing, Dick J., Henk Elffers, and Russell H. Weigel. 1988. Exploring the limits of self-reports and reasoned action: An investigation of the psychology of tax evasion behavior. Journal of Personality and Social Psychology 54: 405-13. [CrossRef]

Hong, Ki Yong, Kap Soon Kim, and Yoon Sung Man. 2016. Tax Justice vs. Religious Belief: The Effects of Tax Professional's Characteristics on the Legislation of Clergy Taxation. The Social Science 11: 5184-90.

Jackson, Betty R., and Valerie C. Milliron. 1986. Tax Compliance Research: Findings, problems, and prospects. Journal of Accounting Literature 5: 125-61.

Kamleitner, Bernadette, Christian Korunka, and Erich Kirchler. 2012. Tax compliance of small business owners: A review. International Journal of Entrepreneurial Behavior Research 18: 330-351.

Kim, Chung K., John H. Evans, and Donald V. Moser. 2005. Economic and equity effects on tax reporting decisions. Accounting, Organizations and Society 30: 609-25. [CrossRef]

Kim, Kap Soon, and Sung Man Yoon. 2017. Taxpayer's Perception to Tax Payment in Kind System in Support of SMEs' Sustainability: Case of the South Korean Government's Valuation of Unlisted Stocks. Sustainability 9: 1523. [CrossRef]

Kim, Soo Na. 2008. Debating of Clergy Taxation and Religion's Social Reliabilities. Non Junior 3: 110-15. (In Korean)

Kirchler, Erich, Erik Hoelzl, and Ingrid Wahl. 2008. Enforced versus voluntary tax compliance: The 'slippery slope' framework. Journal of Economic Psychology 29: 210-25. [CrossRef]

Korea Institute of Public Finance. 2017. Report of 9th Financial Panel Survey. Saejong: Korea Institute of Public Finance. (In Korean)

Kornhauser, Marjorie E. 2009. Cognitive Theory and the Delivery of Welfare Benefits. Loyola University Chicago Law Journal 40: 253-96.

Lee, Won Joo. 2011. A Study on the Taxation System for the Religious Organization and Clergy. Korean Journal of Tax and Law 4: 59-89. (In Korean)

Mohdali, Raihana, and Jeff Pope. 2014. The Influence of Religiosity on Taxpayers' Compliance Attitudes: Empirical Evidence from a Mixed-Methods Study in Malaysia. Accounting Research Journal 27: 71-91. [CrossRef]

O'Donnel, Christopher John, and Daniel. H. Connor. 1996. Predicting the Severity of Motor Vehicle Accident Injuries Using Models of Ordered Multiple Choice. Accident Analysis and Prevention 28: 739-53. [CrossRef]

Porcano, Thomas M. 1985. Distributive justice and tax policy. Accounting Review 59: 619-35.

Porcano, Thomas M. 1988. Correlates of tax evasion. Journal of Economic Psychology 9: 47-67. [CrossRef]

Rechberger, Silvia, Martina Hartner, Erich Kirchler, and Franziska Hämmerle. 2010. Tax amnesties, justice perceptions, and filing behavior: A simulation study. Law Policy 32: 214-25.

Renski, Henry, Asad Khattak, and Forrest Council. 1999. Impact of Speed Limit Increases on Crash Severity: Analysis of Single-Vehicle Crashes on North Carolina Interstate Highways. Transportation Research Record 1665: 100-8. [CrossRef]

Roberts, Michael L., and Peggy A. Hite. 1994. Progressive Taxation, Equity, and Compliance. Law Policy 16: $27-48$.

Rifaat, Shakil Mohammad, and Hoong Chor Chin. 2007. Accident Severity Analysis Using Ordered Probit Model. Journal of Advanced Transportation 41: 91-114. [CrossRef]

Ross, Adriana, and Robert W. McGee. 2011a. Attitudes toward Tax Evasion: A Demographic Study of Malaysia. Asian Journal of Law Economics 2: 1-49.

Ross, Adriana, and Robert W. McGee. 2011b. Attitudes toward Tax Evasion: A Demographic Study of Switzerland. Business Studies Journal 3: 1-47.

Sandmo, A. 2005. The theory of tax evasion: A retrospective view. National Tax Journal 58: 643-63. [CrossRef] 
Song, Ho Dal, and Myung Dol Kim. 2008. A Study on Taxation of Religious Organization. Industrial and Business Review 15: 52-83. (In Korean)

Spicer, Michael W., and Lee A. Becker. 1980. Fiscal inequity and tax evasion: An experimental approach. National Tax Journal 33: 171-75.

Strielkowski, Wadim, and Inna Č́belková. 2015. Religion, Culture, and Tax Evasion: Evidence from the Czech Republic. Religions 6: 657-69. [CrossRef]

Torgler, Benno. 2006. The Importance of Faith: Tax Morale and Religiosity. Journal of Economic Behavior Organization 66: 81-109.

Wenzel, Michael. 2002. The impact of outcome orientation and justice concerns on tax compliance: The role of taxpayers' identity. Journal of Applied Psychology 87: 629-45. [CrossRef] [PubMed]

Wenzel, Michael. 2003. Tax compliance and the psychology of justice: Mapping the field. In Taxing Democracy. Understanding Tax Avoidance and Evasion. Edited by Valerie Braithwaite. Aldershot: Ashgate Publishing Limited, pp. 41-70.

Wenzel, Michael. 2004. The Social Side of Sanctions: Personal and Social Norms as Moderators of Deterrence. Law and Human Behavior 28: 547-67. [CrossRef] [PubMed]

Worthington, Everett L., Jr., Nathaniel G. Wade, Terry L. Hight, Jennifer S. Ripley, Michael E. McCullough, Jack W. Berry, Michelle M. Schmitt, James T. Berry, Kevin H. Bursley, and Lynn O'Connor. 2003. The Religious Commitment Inventory-10: Development, Refinement, and Validation of a Brief Scale for Research and Counseling. Journal of Counseling Psychology 50: 84-96. [CrossRef]

Yitzhaki, Shlomo. 1974. A note on income tax evasion: A theoretical analysis. Journal of Public Economics 3: 201-2. [CrossRef]

(C) 2018 by the authors. Licensee MDPI, Basel, Switzerland. This article is an open access article distributed under the terms and conditions of the Creative Commons Attribution (CC BY) license (http:/ / creativecommons.org/licenses/by/4.0/). 